\title{
Wales: Language and National Identity
}

\author{
By Bedwyr Lewis Jones
}

\section{[Introduction}

When Bedwyr Lewis Jones died very suddenly on Saturday the 29th of August 1992, he left on his writing table the manuscript of his lecture for the conference in a form which was almost complete but which lacked the concluding pages. There were, however, notes indicating the shape of his conclusion and these I have developed, partly in his words and partly in mine.

A.M. Allchin]

F'enaid taw, mae'r haul ar fynd dros y grug i'w gartre, garan wedi mynd i'w nyth, gwartheg yn troi adre.

F'enaid taw, mae'r haul ar fynd.

(Be still my soul, the sun is now about to set/ over the heather home, / the heron has gone to its nest, / cows are turning homeward. / Be still my soul, the sun is now about to set.)

That was a taste of Welsh, a language as distinct from English in its grammatical structure as Danish is from Russian. What I quoted was, in fact, the opening stanza of a translation into Welsh by J. Glyn Davies of Jeppe Aakjær's poem to evening.

A distinct language, Welsh, is the one tangible manifestation of a Welsh national identity. There is no Welsh 'state' in the sense of an organized political community under one government; indeed, it could be argued that there has never been one. Politically, legally, in matters of commerce and industry, Wales is fully integrated with England - more integrated than Scotland. It has a distinct language and history. But that language is very much a 'lesser-used' one. For most of its existence it has been spoken by fewer than 300.000 . For centuries it has co-existed next to the most vigorously expansive language in the world. Today, fewer than one in every five of the people of Wales 
claim to be able to speak it. That it still lives, that poems, plays, and works of fiction from other European languages - including Jeppe Aakjær's poems in Danish - are translated into it, is something of a miracle, a miracle which seems to have impressed Grundtvig.

Welsh has been described by J.R.R. Tolkien as 'the senior British language'. It is the contemporary living form of that dialect of Celtic which was brought to Britain from the continent sometime during the millenium before Christ by people called Celts. This British Celtic or Brythonic was the language of the greater part of mainland Britain when the Romans conquered the island; it was heavily influenced by Latin but it survived the Roman occupation. During the three centuries following Roman withdrawal, however, its territorial domain was reduced drastically and rapidly. Waves of settlers from North Germany and from the Jutish peninsula, people known in Welsh as Saeson or Saxons, took over much the greater part of what was to become England. British Celtic was confined to three limited areas in the west - Cornwall, the land of the Cornovii Welsh, in the southwest; the Strathclyde region around Glasgow in the north-west; and Wales proper. In the Glasgow region Brythonic separateness was to disappear in the twelfth to thirteenth centuries; in Cornwall a Cornish language survived in a minor way until the eighteenth century. Only in Wales was there a continuous, meaningful survival of separateness.

That survival has been a precarious one. Before the end of the eighth century the English king of Mercia, or Middle England, erected a dyke or wall which drew a clear frontier line between the Welsh and the English. Offa's Dyke in parts ran further west than the present administrative boundary of Wales. It marked off a Wales which was small and politically divided, made up of a number of minor kingdoms. During the following centuries one could well have expected such a Wales to have shrunk further. It didn't. The Danish invasions of England in the ninth century had their effect; they served to ease expansionist English pressure. Within Wales three kingdoms were able to consolidate their power, that of Gwynedd in the north, Powys in the centre, Deheubarth in the south. Welsh independent law was codified, giving a sense of unity over and above individual king- 
doms. A view of history was developed which presented the Welsh as the lawful possessors of the Island of Britain in its entirety, a view of the past given brilliant, imaginative and epic expression by Geoffrey of Monmouth in Latin. Welsh saints were honoured and promoted. Poetry and prose tales flourished in the hands of professional bards who were custodians of traditional knowledge and professors of language. In the twelfth century Welsh literature was, unquestionably, one of the richest in Europe. Welshness acquired a depth of cultural meaning far, far beyond the accident of a shared common speech within a particular geographical territory.

All this reached its apex in the thirteenth century. Faced with the growing threat from the latest enemy, the Normans, the royal house of Gwynedd in north Wales led a concentrated effort to establish a feudal Welsh principality extending over a large area of Wales. The attempt had the support of lawyers, bards and ecclesiastics. Briefly a Welsh 'state' flickered. But in 1282 Llywelyn II was killed in battle. An Independent Welsh ruling dynasty was extinguished. "All Wales has been cast to the ground «, wrote one Welsh chronicler at the time. A contemporary court bard put it even more poignantly. In a majestically sonorous, apocalyptic elegy to the dead Llywelyn, he saw the end of everything. Look, see, he cried:

See you not the sun hurtling through the sky?

See you not that the stars have fallen?...

Why, O God, does the sea not cover the land?

What is left to us that we should linger?

There is no place to flee from terror's prison,

Nowhere to hide; wretched is living.

Wales had indeed been conquered, finally. It was subordinated to alien government. A series of massive castles were built to symbolize that subordination - castles as excessively imposing and costly as modern military deterrent symbols.

Politically, all was at an end. Yet Wales and Welshness continued. A thin layer of the topmost level of government disappeared, replaced by alien rulers, but at a lower level a ruling class of Welsh nobility survived. The Welsh language remained domi- 
nant amongst pastoral communities, little affected by alien influence. Poetry was patronised by the native nobility and flourished splendidly. A view of history was cherished, the story of a people with a glorious past who had fallen on bad days but waited hopefully for a deliverer. What one historian has called the lineaments of Welshness endured with little damage to the sixteenth century and another turning point.

In 1536-1542 there was passed an Act of Union of England and Wales. It extended to the whole of Wales the same system of central and local government as for England; for most governmental functions it made Wales part of a British nation-state. The Act was welcomed by the Welsh ruling classes. They saw it as extending to them the same rights and opportunities as all other citizens of an united realm of England and Wales. The fact that the Act included a clause laying down that English was to be the only official language of government was accepted without protest. Attracted by the widening opportunities of an expanding social and economic environment, the natural leaders of Welsh society were increasingly drawn towards the new metropolis. They made for London where their numbers and influence caused them to be mocked as Taffys, a derogatory pronounciation of Dafydd - the Welsh form of David. They, in turn, responded by being more British than the English. The Welsh gentry became Anglicized. Bardic patronage suffered. Welsh bards, long the custodians of collective memory and the guardians of linguistic standards, were marginalized. All this coming at the same time as the spread of printing, the appeal of new learning, the extension of higher education could have had catastrophic consequences for national identity in a country like Wales without an urban centre, without a university. Welsh could well have become a peasant language, a collection of diverging dialects with a heritage of folk-song and folk-tale, but little high culture. Had that happened not only would Wales have been fully assimilated to England politically - Welshness, as one writer feared in 1700, would have been 'Englished out of Wales'.

That did not happen. What did happen was that Welshness was recreated. In this process, religion, and more specifically Protestantism was the influential factor. The state within which 
Wales was incorporated by the Act of Union in 1536 adopted a form of Protestantism as its recognized religion. That meant that Wales became statutorily Protestant. Protestantism stressed the priesthood of all believers; it meant that every individual needed to be provided with the means of knowing God through His Word, through the Bible. The Tudor state which had prescribed that English was the only language of government in Wales, in 1563 passed another Act ordering the translation of the Bible into Welsh. The timing was fortunate. There existed a small group of Welsh scholars, steeped in the linguistic culture of the medieval bards and in the new humanist learning of the Renaissance, who possessed all the skills needed for the task. The New Testament and, then, in 1588 the complete Bible was printed in Welsh. Its influence can hardly be over-emphasized. It gave the Welsh language status. It also gave it an accepted, formal standard which was accepted by later authors. Initially, its influence was limited, but with the popular religious reformation of the eighteenth century Biblical standard Welsh became a widely common possession. Early in that century a system of circulating voluntary schools was established by Griffith Jones. An itinerant teacher would set up school in a district for three months when work on the farm was at its slackest. The underlying motive was evangelical; it was to save souls, not to foster Welshness. But the immediate purpose was to teach those who attended to read the Welsh Bible.

It has been estimated that, by $1771,200.000$ persons, or half the population of Wales, had attended these reading classes - a means of education which was, incidentally, held up as a model almost fifty years ago by UNESCO. A significant percentage of ordinary Welsh men and women were made literate in their native language. That literacy was extended by the popular religious awakening known as the Methodist Revival. Again, the purpose was to save souls. Those who were converted were gathered together in 'societies'; the 'societies' grew into churches outside the provision of the established state church; these independent churches established Sunday Schools which provided a comprehensive religious education for all age groups, from elementary reading classes to advanced theological discussion. All was in Welsh. The spoken tongue was reinforced with the rich- 
ness of scriptural language. Culturally, the effect was revolutionary. One of the leaders of the Methodist Revival, William Williams, was, like Grundtvig, a particularly gifted hymn writer. He wrote and published some 800 Welsh hymns. These, and hymns composed by others inspired by Williams, became the folk-songs of a numerous, serious, pious, book-reading and bookbuying public. Welshness entered the nineteenth century revitalized religiously and linguistically.

The nineteenth century saw Wales transformed industrially and demographically. A population which had remained comparatively stable at between 250.000 and 300.000 increased dramatically. By 1851 it was more than a million; by 1914 it was over 2.5 million. What had been a dispersed rural community where most people lived off the land was transformed into a complex industrial society with a population concentrated in certain areas - in the south east in particular: $42 \%$ of the population of Wales in 1851 lived in Glamorgan and Monmouthshire.

Rapid economic change of this kind, involving large-scale migration of people, is usually presented as a hostile threat to regional languages and identity. In Wales the result of the industrial revolution, at least in its earlier phase, was to strengthen Welshness. Migration to a considerable degree was internal migration, from the rural agricultural areas to the South Wales coal mining valleys, in North West Wales to the slate quarries. Wales, unlike Ireland, retained its population. The number of Welsh speakers grew from 300.000 to a million. Towns and populous villages developed which were Welsh in speech and character, all with an ample provision of Nonconformist - that is, non established Church - chapels and meeting houses. One must not give the impression that the whole of Wales was one big chapel; significant numbers of people were little touched by religion. It is a fact, however, that the proportion of the population involved in active chapel membership was appreciably higher in Wales than in England. Religion was a compelling force in society. Chapels became centres of social and cultural activity, including choral singing.

The chapels also developed a new leadership, articulate in its native language. This leadership, as the century advanced, became increasingly politicized. The gentry had become Anglicized; 
they were English in speech and outlook, Established Church in religion. They lost touch with their tenants who were Welsh and Nonconformist. With the extension of the franchise and increasing democratization a new leadership emerged which was politically radical.

Welshness was acquiring ingredients other than distinction of language. Nonconformity, Dissent in religion, was one element. Radicalism in political outlook was another. This awareness of otherness was sharpened with the publication in 1847 of a Government Report on the state of education in Wales. Provision of day-school education was indeed poor. The Report rightly noted its inadequacy. But the English authors of the Report did not confine themselves to reporting, they interpreted. They attributed what they saw as the backwardness of Wales the ignorance of English among children - to the existence of the Welsh language. They went even further; they implied that the Welsh people were backward, indolent, immoral because of the Welsh language and Nonconformity. The new Welsh leadership reacted. The Report became known as The Treason of The Blue Books. There was an energetic public campaign to defend Welshness. A note of nationalism appeared in Welsh politics, encouraged by the example of nationalist movements in continental Europe - in Hungary for example. In later years, the Young Wales which David Lloyd George championed when he entered Parliament in 1890 talked of Home Rule for Wales. Nothing came of it. In retrospect one can see that the idea of Home Rule canvassed lacked political content; one can question the commitment of the leader of Welsh Radicalism to SelfGovernment. But that political Radicalism did secure Acts of Parliament to establish a system of secondary and university education in Wales and to close public houses in Wales on Sundays. These Parliamentary Acts recognized Wales as a distinct entity. They were a manifestation of nationhood, as was the establishing of a Natinal University and a National Museum.

A leading Welsh scholar writing a century ago, could conclude an article on the Welsh language with a sense of national pride and confidence. I quote: 
»More people speak the language than ever in its history; it is more widely read in proportion to its speakers than, possibly, any other language... It has at last been given recognition by the British government; Acts of Parliament and other parliamentary papers were translated into it ... A century ago it was prophesied that it would be extinct within a hundred years. No-one today would utter a similar prophecy.«

One can understand his confidence. A million people spoke Welsh. Over much the greater area of territorial Wales it was the dominant language, spoken by over $70 \%$ of the population over $90 \%$ in extensive areas. This linguistic heartland included, as well as rural Wales, two industrial or semi-industrial regions the anthracite coal-mining valleys of South Wales and the slate quarrying villages of Gwynedd. Throughout this area a mesh of Nonconformist chapels provided a unifying cultural framework with its own indigenous leadership and its structure of synods, assemblies and national organizations. A viable press flourished, a press which was commercially self-sufficient. There were twenty Welsh-language weeklies. A denominational children's magazine distributed over $\mathbf{4 0 . 0 0 0}$ copies. The words of the scholar which I quoted about the secure future of the language came from the second edition of a ten volume Welsh encyclopaedia which was a successful commercial venture.

Departments of Welsh in the new University made available texts of the literary classics of the past; they became a breeding ground for a new generation of creative writers who were to lead a splendid renaissance in literature. An Oxford trained historian, Owen M. Edwards, popularized the new learning. He provided a new history, linking the achievements of Nonconformity and Radicalism with that of the independent medieval princes in an heroic national story. Edwards can, in many ways, be compared with Grundtvig. With amazing energy he published attractively presented books and magazines which spread information about Welsh history and tradition, including folk-lore and local tradition. He helped to create a new folk-memory. Edwards also set out to give Welsh and Welsh tradition a place in school education. The provision of state day schools had come late in 
Wales, as in England - much later than in other European countries. When it came, especially after 1870, it was an English orientated education; its aim was to teach English to Welsh children. In some schools, pupils were punished for speaking their native language. O.M. Edwards, who left a scholar's career at Oxford to become Chief Inspector of Schools in Wales, sought to change this policy. There was idealism in the air concerning Welshness, a vision of a new age dawning. Poets could write of King Arthur returning.

The confidence was, however, illusory. A million may have spoken Welsh in 1900, but the population of Wales was two million. Half the people spoke English only. This non-Welsh speaking population was concentrated primarily in the southeast corner where the later phases of industrial development, from 1860 onwards, had seen heavy immigration of workers from outside Wales. Large towns grew - at Cardiff, Swansea, Newport; these were predominantly English. In urban centres throughout Wales there had been a steady growth in the use of English. These changes were to continue in the early decades of this century. Welsh and Welshness were nowhere nearly as secure as they seemed to appear from within the fortress of the Welsh heartland.

The economic depression of the inter-war years and the resultant migration of Welsh workers out of Wales in search of employment weakened the position of the language further. Total numbers of Welsh speakers fell from a million in 1900 to 700.000 in 1950 , a loss of 300.000 . Those who did not speak Welsh - five out of every ten of the population in 1900 , seven out of ten in 1950 - were by definition outside the hold of Welsh chapel Nonconformity. Their education was almost entirely English. Politically their aspirations were expressed through tradeunionism and socialism, both of which were in the main English in speech and international in outlook, suspicious of national sentiments. For the majority of the people of Wales what had been the lineaments of Welshness in the nineteenth century - a distinct language, chapel membership, a national history, were becoming increasingly meaningless and irrelevant. Indeed, for the many, Welshness had little more content than a sentimental attachment to singing and rugby. 
In 1925 a political party was founded with the aim of obtaining self-government and safeguarding cultural distinctiveness. It looked to other small nations for inspiration and example - to Denmark, for instance: it published in 1944 an introduction to the work and ideas of Grundtvig. The popular support which it attracted was minimal.

The Welsh Language remained dominant in rural areas. Here Nonconformist chapels retained the allegiance of large numbers. A distinctive literary culture continues to flourish.

I was brought up in the Forties and early Fifties in such an environment. Its Welshness then seemed cosily all-pervading and secure. But already here, in what can be conveniently called Welsh Wales, there were forces at work weakening cultural separateness. Mobility was one factor, the end of physical isolation. Increased exposure to English was another.

\section{Conclusion}

[At that point Bedwyr Lewis Jones' text ends. The notes which he left indicate the shape of his conclusion and in what follows I have followed them closely, though expanding and developing them. A.M. Allchin]

He went on to say that, "The depressing graph of decline «, which he had described in the earlier part of this century continued until very recently. Indeed, many think that it still continues. He comments that this is not only a numerical decline. "For some time it appeared, and to some extent it still appears, as if the language in the Welsh heartland is being impoverished. Signs of that impoverishment are loss of idioms, loss of vocabulary, loss of metaphors from common speech.«

I may add, that Bedwyr Lewis Jones made it his own particular task to combat that tendency. He added to his purely academic work a remarkable activity of popular education. He wrote a weekly column in Welsh in the principal English-language newspaper of Wales commenting on points of linguistic usage. He also presided over a very popular phone-in programme on Welsh radio. Listeners would phone in with queries about place-names, proverbs, old sayings and expressions which they did not always 
fully understand and Lewis Jones would respond with a wonderful mixture of humour and scholarship. But how far could such efforts be availing? He writes, "The whole situation could be summarized for the supporters of the language as pessimism of the mind even if there is optimism of the will."

But he then goes on to note that at present the situation seems to be changing. There have been heartening signs. He notes five of them:

a) The establishing of Welsh schools, especially in anglicized areas, and the substantial increase in the number of Welsh learners. Some of these schools which teach through the medium of Welsh have been outstandingly successful, and many parents who do not themselves speak Welsh have been anxious to send their children to them so that they may grow up knowing both languages. This is a new development. Equally new is the rapid increase in the number of adults who are learning the Welsh language. It is true that many of these learners do not progress very far, but an increasing number do in fact master Welsh. In 1992, for instance, a book was published called Discovering Welshness (Gomer Press) which contains accounts by people who have learned Welsh, telling why they learnt the language and what they discovered in doing so. Among them are not only Welsh and English people, but also Americans and one Dane.

b) The increasing use of the Welsh language in public administration, in the post office and in local government for instance, is also heartening. Here reference is made to the activities of the Welsh Language Society which over the past thirty years has been very active and at times militant in promoting the use of the language in a great variety of ways. The initial inspiration for the establishment of the society came from a radio lecture on the fate of the language given in 1962 by the outstanding Welsh writer Saunders Lewis.

c) Many of these advances have been facilitated by the Welsh Language Act which was passed by the London Parliament in 1967 and which gives Welsh a measure of legal recognition in public affairs. The legal and constitutional position of the language is still by no means satisfactory from the Welsh point of view but is much better than it was. In the courts of 
law, in the transaction of business and commercial affairs, the legality of the Welsh language is recognized more clearly than before.

d) In 1982 a Welsh language television channel was established which assures that a good proportion of each evening is given to programmes in Welsh. This concession was gained from the government in London by the threat of the leader of the Welsh Nationalist Party to fast to death. Gwynfor Evans was a man universally respected in Wales by his opponents as well as his supporters and the government wisely gave way. The television channel has acted as a stimulus for all kinds of activity, especilly in the field of popular writing and music.

e) The results of the most recent census in Great Britain which took place in 1991, though they are not yet fully available, seem to be promising, particularly in what they show about young people speaking Welsh. It looks as if the decline in the number of Welsh speakers is at last being checked.

In conclusion, Lewis Jones writes, "As it has been throughout most of the history of Wales, the Welsh language is the main marker of Welsh identity. The challenge for the future of the language is that the bilingual situation should be stabilized. In an increasingly cosmopolitan culture it is important that the cultural intheritance enshrined in the lore and literature of the past should still be transmitted.«

In an editorial in the August number of the literary periodical Taliesin which Bedwyr Lewis Jones edited in collaboration with his friend R. Gerallt Jones, the editors remark on their fear that a generation is growing up in Wales that fails to value the whole content of the literary tradition which the language enshrines. That tradition they affirm needs to be reappropriated. It contains within it the record of the historical experience which has made the Welsh people what they are. 